\title{
Tabularia
}

TABULARIA Sources écrites des mondes normands médiévaux Les sources comptables, méthodologie, critique et édition | 2006

\section{A new edition of the Norman Pipe Rolls}

Une nouvelle édition des rôles de l'échiquier de Normandie

\section{Vincent Moss}

\section{(2) OpenEdition}

\section{Journals}

\section{Electronic version}

URL: http://journals.openedition.org/tabularia/888

DOI: $10.4000 /$ tabularia. 888

ISSN: $1630-7364$

\section{Publisher.}

CRAHAM - Centre Michel de Boüard, Presses universitaires de Caen

\section{Electronic reference}

Vincent Moss, "A new edition of the Norman Pipe Rolls », Tabularia [Online], Les sources comptables, méthodologie, critique et édition, Online since 09 May 2006, connection on 02 May 2019. URL : http:// journals.openedition.org/tabularia/888; DOI : 10.4000/tabularia.888 


\title{
A new edition of the Norman Pipe Rolls
}

\section{Une nouvelle édition des rôles de l'Échiquier de Normandie}

\author{
Vincent MOSS \\ Lecturer University of the United Arab Emirates \\ vincent.moss@btinternet.com
}

\begin{abstract}
:
The article introduces the first volume of the new edition of the Norman Pipe Rolls and critically examines previous editions. It argues that the Stapleton edition was never finished (due to his ill health) and that manuscripts he failed to thoroughly examine provide the key to understanding the Norman pipes i.e. that these rolls were not made at the seating of the Norman Exchequer but are copies. It argues that all previous comparisons between the forms of the English and Norman pipe roll are therefore redundant since the Norman manuscripts can only be compared to the unpublished chancery and other copies of the English Exchequer which the Norman Pipe rolls strongly resemble.
\end{abstract}

Keywords: Norman Pipe Rolls, new edition, Stapleton, Léchaudé d'Anisy.

\section{Résumé:}

Cet article présente le premier volume de la nouvelle édition des rôles de l'Échiquier de Normandie et examine de façon critique les éditions précédentes. Il affirme que l'édition de Stapleton n'a jamais été achevée (en raison de la mauvaise santé de l'auteur) et que les manuscrits que ce dernier n'a pas réussi à parfaitement examiner fournissent la clé pour comprendre les rôles normands. En effet, ces rôles n'ont pas été réalisés à l'occasion d'une session de l'Échiquier de Normandie; ce sont des copies. Il affirme que toutes les comparaisons précédentes entre les formes des rôles anglais et normands sont par conséquent superflues puisque les manuscrits normands peuvent seulement être comparés aux copies non publiées - celles de chancellerie et les autres - de l'Échiquier anglais auxquelles ils ressemblent fort.

Mots-clés: Rôles de l'Échiquier de Normandie, nouvelle édition, Stapleton, Léchaudé d'Anisy.

The first volume of the new edition of the Norman Pipe Rolls and related material has recently been published ${ }^{1}$. This volume contains entirely new transcriptions of E 373/10 (the Norman pipe roll of 1179-1180) and E 373/1 (part of the Norman pipe roll of 1183-1184) both of which are held at the English National Archives in Kew. It also includes a new transcription of S. 4824 no. 1 (another part of the Norman

1. Moss, Vincent (ed.), Pipe Rolls of the Exchequer of Normandy for the reign of Henry II, 1180 and 1184, Loughborough, Pipe Roll Society, 2004, XCI New Series, 106 p. 
pipe roll of 1183-1184) held in the Archives Nationales in Paris. The second volume will concern the reign of Richard I and will include new transcriptions of the pipe rolls of 1194-1195 and 1197-1198 and an introduction to these texts. Volume three will contain new transcriptions of the limited surviving records from the Norman pipe rolls of the reign of King John for the years 1200-1201 and 1202-1203 and the surviving extractus memorandi (documents utilized in the preparation of the Norman pipe rolls that contain Exchequer material dating to years for which there are no surviving Norman pipe rolls). It will also include a new introduction both to the Norman pipe rolls of King John's reign and the extractus memorandi. The final volume will consist of a detailed name and place index to the three volumes, maps illustrating the changing nature of administrative boundaries in Normandy between 1179-1180 and 1202-1203, and a detailed general introduction to the rolls and functioning of the Norman Exchequer as well as any corrections to the pipe roll texts and introductions.

\section{Previous Editions}

With the exception of S. 4824 no. 1 the rolls transcribed in the first volume were originally printed, in record type, by Thomas Stapleton ${ }^{2}$. An earlier transcription of the Norman pipe roll of 1183-1184 was privately published by Henry Petrie ${ }^{3}$. Regrettably the damage done to E 373/1 had already occurred by 1830 and the transcription is inferior to that of Stapleton. Archives Nationales, Paris S. 4824 no. 1, another part of the roll of 1183-1184, was transcribed by Leopold Delisle and published as Magni Rotuli Scaccarii Normanniae de anno Domini ut videtur MCLXXXIV Fragmentum (Caen, 1851), p. 43-55; it was later reprinted in L. Delisle, Recueil des actes de Henri II introduction (Paris, 1909), p. 334-344. The latter transcription has been the one most commonly consulted by scholars.

The most readily available and frequently consulted edition of the Norman pipe rolls found in French libraries and archives is that published by Léchaudé in 1851 and $1852^{4}$. The reason for this is that, unlike the Stapleton text, the Léchaudé edition contains an index to the rolls. The Léchaudé text is not an independent transcription of the Norman pipe rolls (it repeats Stapleton's errors), but rather a reworking of the 1840 and 1844 edition. The major differences compared to the Stapleton edition is that the numerals were converted from a Roman to an Arabic form and that some of the Latin was extended although often incompletely and on occasions

2. Stapleton, Thomas (ed.), Magni Rotuli Scaccarii Normaniae sub Regibus Angliae, London, Society of Antiquaries, 1840 and 1844, 2 volumes, p. 1-106, 109-123. Here after referred to as MSRN.

3. Petrie, Henry (ed.), Magni Rotuli Scaccarii Normanniae de anno ab incarnatione Domini 1184. Willelmo filio Radulfi Senescallo, quae extant, London, 1830.

4. LÉCHAUdÉ D’ANISY, Amédée-Louis (ed.), Grands Rôles des Échiquiers de Normandie, Mémoires de la Société des antiquaires de Normandie, 1851, XV, p. 137-214. Magni Rotuli Scaccari Normanniae sub regibus Angliae pars secunda, MSAN, 1852, XVI, p. 214-290. 
incorrectly. It also contains a number of errors simply committed in copying Stapleton's transcription. The new edition should end the situation where generally French scholarship studies the Norman pipe rolls through the badly distorted mirror of an old transcription with its own errors reworked through a marginally younger revised and inexact copy of this transcription with its own very many faults and errors.

A particular advantage in preparing these editions has been provided by modern technology. The condition of the manuscripts is not what is was in the 1840's and on many occasions (particularly as regards E 373/1 and E 373/2). I have been forced to rely on the Stapleton's transcription since parts of the manuscript have been torn away since his edition. On the other hand the conversion of a micro-film copy into a digital form and the subsequent utilization of photo-shop combined with the use of ultra violet light in the National Archives at Kew has sometimes allowed me to see and transcribe faded or dirty parts of the manuscript which Stapleton could not read. A particular benefit of the use of photo-shop in the preparation of this edition has been the use of 'curves' (essentially a tool which alters contrasts as well as darkness and light) to reveal and transcribe very faint sometimes important deletions which it is possible Stapleton could not see.

\section{The Stapleton Edition}

Stapleton's edition of the Norman pipe rolls published in two volumes in 1840 and 1844 respectively is rightly regarded as one of the great pioneering achievements of nineteenth-century scholarship. The introductions to his two volumes edition constitute a remarkable and diverse act of historical retrieval illuminating such critical matters as the power and resources of the duke, the geographical boundaries of the Norman bailliages and the relationships between church and state in the duchy. Even today the introductions to these two volumes still have a seminal place in the study of the prosopography of the Norman aristocracy for modern scholars ${ }^{5}$. Stapleton's transcription was, even beyond the context of its time, a remarkable achievement. The difficulties associated with Stapleton's edition stem to some extent from its very pioneering character (Stapleton had so many new decisions to make it would have been surprising if he was not on occasion in error) and more importantly from the fact that the author's illness meant that the edition was never finished. The Latin in Stapleton's edition was left unexpanded. The edition contains no index to the rolls; although Stapleton's introduction was indexed. Particularly in the first volume and not uncommonly in later volumes Stapleton chose not to record most deletions and on many occasions Stapleton failed to indicate interlineations. These two latter practices were almost certainly deliberate editorial decisions rather than inconsistencies. Stapleton did include examples of deletions and interleations which he considered to be important; though his choices would not necessarily be those of modern

5. MRSN, i-cclxvii. 
scholars ${ }^{6}$. Given the early date of the edition Stapleton was naturally not familiar with all the forms of transposition marked on the Norman pipe rolls. There are also in his edition (perhaps unsurprisingly given his ill health and the remarkable speed with which Stapleton completed his work) a number of straight forward errors. Taking all of these factors into account there are well over a thousand errors and omissions in the Stapleton edition as a whole and over three hundred corrected in the first volume of the new edition.

\section{The Manuscripts}

In a very important sense Stapleton's edition was never finished. The collection of the Norman pipe rolls found in the National Archives at Kew consists of eighteen manuscripts (E 373/1-18); fourteen of these date solely to the reign of King John, E 373/2 which contains a roll from the time of Richard I as well as part of the 1202-1203 Norman pipe roll and another three manuscripts (E 373/1, E 373/10 and E 373/18) that date respectively to the reigns of Henry II and Richard I. Of the thirteen manuscripts that concern the pipe roll of 1202-1203 there are six that have been categorised as copies of parts of that roll (E 373/3, E 373/6, E 373/11, E 373/8, E 373/15, E 373/12). All of the rolls with the exception of the roll of 1197-1198 and part of 1202-1203 found in E 373/2 are now separate, but this has not always been the case. In 1917 E 373/1, 2, 10, 18 were fastened together in some manner presumably E 373/1 with E 373/10 (the rolls of Henry II) and E 373/2 with E 373/18 (the rolls of King Richard and part of the roll of King John) ${ }^{7}$. In Stapleton's day all of the surviving manuscripts were rolled together and fastened to some extent ${ }^{8}$. By following Stapleton's edition of the 1202-1203 Norman pipe roll, it is possible to deduce the order in which some of these manuscripts were fastened together (E 373/9, E 373/2, E 373/4, E 373/7, E 373/16, E 373/14, E 373/13, E 373/17). On the other hand, at an earlier time the rolls that now constitute E 373/2 were once separate 9

Unfortunately Stapleton did not reveal in his edition which manuscripts he utilized in his transcription, but by comparing his transcription with the surviving manuscripts we can, with some difficulties, deduce which manuscripts he transcribed and to what extent he utilised information found on manuscripts he regarded as copies. Stapleton's method in transcribing the Norman pipe rolls from the reigns of Henry II and King Richard is relatively easy to reconstruct. The 1179-1180 Norman pipe roll (in Stapleton's edition p. 1-106) was a transcription of E 373/10 and the

6. I was somewhat surprised to note that Stapleton failed to record the deletion of the first line of entries of a deleted and hitherto unknown judicial and tallage account levied at Caen in Normandy in the 1190's. A full discussion of this will occur in volume two of the new edition.

7. JENKINSON, Hilary, "Financial Records of the Reign of King John" in Magna Carta Commemoration Essays, Henry Elliot MALDEN (ed.), London, Royal Historical Society, 1917, p. 262-263, footnote 2.

8. MRSN, i, ix.

9. Website National Archives Catalogue E 373/6. http//www.nationalarchives.gov.uk. 
source of the section of the 1184-1185 roll that Stapleton transcribed (p. 109-123 in his edition) was E 373/1. The 1194-1195 roll (in Stapleton's edition p. 127-288) was a transcription of E 373/18 and the 1197-1198 roll was transcribed from the first part of E 373/2 which were recorded as p. 289-497 in Stapleton's edition (the rest of this manuscript contains part of the 1202-1203 roll). The small surviving manuscript from the Norman pipe roll of 1200-1201 was simply a transcription of E 373/5 (in Stapleton's edition p. 501 and 502). The returns from Cherbourg in the bailliage of the Cotentin on the 1202-1203 roll (in Stapleton's edition p. 572-574) was a transcription of E 373/17 and the accounts from bailliage between the Risle and the Seine (in Stapleton's edition p. 560-568) was a transcription of E 373/14.

The difficulties are in working out to what extent Stapleton utilised what he regarded as copies of sections of the 1202-1203 roll. We cannot be totally certain as to what Stapleton precisely did since damage to the manuscripts may well have been less and the sections of the text more legible in the 1840's than today, but assuming the manuscripts were in roughly the same state as they are currently, we can get remarkably close to reconstructing his approach. The first part of the returns of the bailliage of the Cotentin (p. 505-511 in the Stapleton edition) was simply a transcription of E 373/9. The copy of this record (E 373/3) was not utilised by Stapleton despite the fact that this manuscript contains alternative spellings of names and places as well as on occasions more full Latin expansions. The returns from the bailliage of Vire (in Stapleton's edition p. 531-537) were essentially a transcription of E 373/4. The supposed copy of this record (E 373/11) was (probably) used to provide text where E 373/4 was not legible or damaged. But E 373/11 contains a considerable number of alternative spellings and alternative names as well as many expansions not found in E 373/4 which Stapleton, except for one name in brackets (p. 533), did not utilize. The transcription of the 1202-1203 account concerning Caen (in the Stapleton edition p. 568-571) was drawn from E 373/13. E 373/12 was not utilized though this copy contained a different location for building work of the king than that cited and deleted in E 373/13 and also included many expansions not found in the original. Stapleton's approach in the transcription of the bailliage of Mortain (p. 538-548 in his edition) is especially difficult to reconstruct since the two manuscripts concerned are both dirty and in many places barely legible, but essentially Stapleton used E 373/7 to construct the main body of his transcription and probably utilised E 373/8 only where E 373/7 was illegible. Again the very many differences of spelling and the more full Latin expansions in E 373/8 were not recorded by Stapleton. The returns from the bailliages of Roumois and Pont-Audemer (in Stapleton's edition p. 549-560) were essentially a transcription of E 373/16. Its copy E 373/15 was only used to provide information where E 373/16 was damaged, and again Stapleton did not record differences of spelling or the often more full expansions found in $\mathrm{E} 373 / 15$.

Understanding Stapleton's utilisation of E 373/2 and its supposed copy E 373/6 provides the clearest measurement of Stapleton's progress in the utilisation of information found on the copies of parts of the 1202-1203 roll. In Stapleton's edition part 
of E 373/2 was used in his transcription of the 1202-1203 roll to provide the returns from the bailliages of Gavray and Coutances (p. 512-530). In compiling this part of his edition Stapleton began the process of recording differences found in E 373/6 which he regarded as a copy of the returns from 1202-1203 found in E 373/2. This is recorded in his edition as Addenda et mutanda ex m. duplicata (p. 574-575). This recording of differences found in E 373/6 was not completed since it ended only a third of the way through the bailliage of Coutances (p. 523 in Stapleton's edition). E 373/6 is not a copy of E 373/2 since it includes debts from individuals not found in $\mathrm{E} 373 / 2$, nor can $\mathrm{E} 373 / 2$ be regarded as a copy of $\mathrm{E} 374 / 6$ since it contains a debt from an individual not found in E 373/6. We can therefore be certain that Stapleton had not reached the point in his addenda et mutanda ex $\mathrm{m}$. duplicata where these two manuscripts diverged since he could not fail to note such an important piece of evidence that had (and has) profound significance for the functioning of the Norman Exchequer and would have altered his whole approach to the production of his transcription of the Norman pipe roll of 1202-1203. Further evidence of the unfinished character of Stapleton's edition is indicated by footnote ' $a$ ' in the transcription of the roll of 1202-1203 found at the end of the returns of the bailliage of Vire (p. 537) which reads vide postea inter additamenta pro hoc compoto. In fact Stapleton failed to deliver this promise since as we have seen Addenda et mutanda ex m. duplicata finished well before the account from the bailliage of Vire (p. 531-537).

Stapleton's use of the manuscripts can thus be summarized below.

\begin{tabular}{|c|c|c|}
\hline $\begin{array}{c}M S R N, \\
\text { pages }\end{array}$ & Date & Manuscripts \\
\hline $1-106$ & $1179-1180$ & Norman pipe roll E $373 / 10$ \\
\hline $109-123$ & $1183-1184$ & Norman pipe roll E 373/1 \\
\hline $127-288$ & $1194-1195$ & Norman pipe roll E $373 / 18$ \\
\hline $289-497$ & $1197-1198$ & Norman pipe roll part of E $373 / 2$ \\
\hline $501-502$ & $1200-1201$ & Norman pipe roll E $373 / 5$ \\
\hline $505-511$ & $1202-1203$ & Norman pipe roll E 373/9 (E 373/3 not utilized) \\
\hline $512-530$ & $1202-1203$ & $\begin{array}{l}\text { Norman pipe roll E 373/2 Some of the differences found in } \\
\text { E 373/6 which Stapleton regarded as copy of E 373/2 were } \\
\text { recorded in Addenda et mutando ex m. duplicata, p. 574-575, } \\
\text { in Stapleton, but the task was never finished. }\end{array}$ \\
\hline $531-537$ & $1202-1203$ & $\begin{array}{l}\text { Norman pipe roll E } 373 / 4 \text { (E } 373 / 11 \text { only used where } \\
\text { E } 373 / 4 \text { was damaged and a alternative spelling) Stapleton } \\
\text { (footnote p. } 537 \text { vide postea inter additamenta pro hoc com- } \\
\text { poto) promised to record these differences in his addenda, } \\
\text { but did not do so. }\end{array}$ \\
\hline $538-548$ & $1202-1203$ & $\begin{array}{l}\text { Norman pipe roll E 373/7 (E 373/8 only used by Stapleton } \\
\text { where E } 373 / 7 \text { damaged) }\end{array}$ \\
\hline
\end{tabular}




\begin{tabular}{|l|l|l|}
\hline $549-560$ & $1202-1203$ & $\begin{array}{l}\text { Norman pipe roll E 373/16 (E 373/15 only used where } \\
\text { E 373/16 damaged) }\end{array}$ \\
\hline $560-568$ & $1202-1203$ & Norman pipe roll E 373/14 \\
\hline $568-571$ & $1202-1203$ & Norman pipe roll E 373/13 (E 373/12 not utilized) \\
\hline $572-574$ & $1202-1203$ & Norman pipe roll E 373/17 \\
\hline
\end{tabular}

Table 1: Stapleton's use of the manuscripts

We can reconstruct pretty accurately how far Stapleton had got in the preparation of the 1202-1203 roll before ill health prevented him finishing the task. He had chosen which manuscripts he would use to provide the text of this roll and had transcribed them. He had therefore decided which manuscripts were 'originals' and which he considered to be copies. He had utilised all of the copies to the extent of recording text where the 'original' manuscripts were damaged or illegible. He had recognised that the greatest differences between the text of the supposed 'copies' and those of the supposed 'originals' were to be found in E 373/6 and E 373/8 and had started recording these differences as regards the first part of E 373/6. He had also indicated one important change of name found on the E 373/8 compared to E 373/7 by the use of brackets. But Stapleton had not completed the recording of differences found in E 373/6 and with the one exception indicated above had yet to record the differences found in the five other manuscripts that he regarded as copies. Thus the critically important transcription of the 1202-1203 utilized by a host of scholars to consider the loss of Normandy was in fact never finished by Stapleton. This task will be completed in volume three of the new edition.

Perhaps the most important consequence of the unfinished character of the Stapleton edition was the failure to complete the comparison of E 373/2 and E 373/6. These manuscripts cannot be the rolls originally written at the sessions of the Norman Exchequer since they both contain independent information which can only have come from an original pipe roll (presumably prepared by and at the Exchequer) that does not survive. The Norman accounts strongly resemble the chancery copies made of the English Exchequer pipe rolls that condense information of those who have cleared their debts in relatively large blocks of texts and regularly utilise summa to record the value of these entries in roughly the same manner as the Norman pipe rolls ${ }^{10}$. Given the common recording of dense blocs of text ended by the total owed in all of the manuscripts a strong case can be made that all of the surviving Norman pipe rolls are in fact copies ${ }^{11}$. All of this has important consequences for volume three

10. The blocks of paid entries found on the Norman pipe rolls of Henry II are generally larger than those on the English chancery copies, but this is almost certainly because more Norman debts were paid. For the latter point see Moss, Vincent, "England and Normandy in 1180: The Pipe Roll Evidence", in England and Normandy in the Middle Ages, David BATES and Anne CURRY (eds.), London and Rio Grande, The Hambledon Press, 1994, p. 193-194.

11. The reason for the use of the summa on the chancery copies and the distinctive functions of the copies as compared to the original pipe rolls will be discussed in volume four of the new edition. 
of the new edition of the Norman pipes rolls since Stapleton's selection of the texts to make his transcription of the 1202-1203 roll was based on what must be the false premise of sorting out 'originals' from 'copies' in the surviving records and using the supposed 'originals' as the manuscripts from which to prepare his transcription. Volume three of the new edition will be prepared on the basis of an entirely different approach to that utilised by Stapleton. The manuscripts that are the most detailed will be used to provide the transcription and differences found in other copies will be recorded through copious footnotes. A further consequence of the designation of the surviving Angevin Norman pipe rolls as copies is that three times more Norman Exchequer material must be missing than was previously thought to be the case. This suggests that a disproportionate amount of Angevin twelfth-century documentation produced at Caen failed to survive. Such an uneven pattern of survival is not incongruous with the pattern of the surviving royal acta since only 56 charters of Henry II made at Caen survive out of 1254 charters made in Normandy compared to 152 issued at Rouen and sixty issued at Argentan ${ }^{12}$. Finally the identification of all the existing Norman pipe rolls as copies of Exchequer rolls that do not survive has important consequences for our understanding of the Norman Exchequer. Many of the differences in form between the English and Norman Exchequers rolls suggested by Haskins, Jenkinson and myself must now be regarded as redundant ${ }^{13}$. Comparisons of the way in which information was recorded in the English and Norman Exchequers can only be made by comparing the Norman pipe rolls not with the published pipe roll editions but the unpublished chancery copies of the English pipe rolls which strongly resemble the Norman manuscripts. It is hard to avoid the conclusion that in their form the Norman and English pipe rolls were far more alike than has previously been suggested ${ }^{14}$.

The first volume of the new edition of the Norman pipe rolls marks an important moment in the publication of a series of editions of important texts that centrally concern the until recently badly neglected subject of Angevin Normandy including a new edition of the charters of Kings Henry, Richard and John. All of this new material should provide a basis for a thorough reexamination of society, power, finance and government in Angevin Normandy.

12. VInCENT, Nicholas, "Les Normands de l'entourage d'Henri II Planagenêt" in La Normandie et L'Angleterre au Moyen Âge, Pierre BOUET and Véronique GAZEAU (eds.), Caen, Publications du CRAHM, 2003, p. 81.

13. Jenkinson, Financial Records..., p. 270-273. HASKIns, Charles Homer, Norman Institutions, New York, Frederick Ungar Publishing Company, Constable and co., 1960 reprint, p. 39-48, 177. Moss, Vincent, "The Norman Fiscal Revolution" in Crises, Revolutions and Self Sustained Growth, Mark ORMroD, Margaret BONNEY and Richard BonNEY (eds.), Stanford and Oxford, Alden Group, 1999, p. 39.

14. Volume four of the new edition will contain a detailed discussion of these issues. 